\title{
Audit Socialization and Professional Success: Evidence from Thailand
}

\author{
Kornchai PHORNLAPHATRACHAKORN ${ }^{1}$, Khajit NA KALASINDHU ${ }^{2}$
}

Received: September 10, 2020 Revised: November 08, 2020 Accepted: November 16, 2020

\begin{abstract}
The objective of this study is to examine the effects of audit socialization and professional commitment on professional success of tax auditors in Thailand through individual learning as the moderator. The specific research questions are: (1) How audit socialization affects professional commitment, (2) How professional commitment influences professional success, and (3) How individual learning moderates the audit socialization-professional commitment relationships, the audit socialization-professional success relationships, and the professional commitment-professional success relationships. This study collected data from 249 tax auditors in Thailand by using questionnaire. To investigate the research relationships, both structural equation model and multiple regression analysis are implemented. Within the research results, audit socialization has a significant positive effect on professional commitment and professional success while professional commitment has an important positive influence on professional success. Similarly, individual learning positively moderates the professional commitment-professional success relationships. In summary, audit socialization is important for auditing professions and it is a key determinant of professional success. Thus, auditors need to pay attention to audit socialization through learning and understanding it and applying its concepts to audit works to increase auditors' professional success, continuous survival and long-term sustainability.
\end{abstract}

Keywords: Audit Socialization, Professional Commitment, Individual Learning, Professional Success, Tax Auditors

JEL Classification Code: M41, M40

\section{Introduction}

Recently, auditors have become key players in defining, determining, identifying, assuring, and guaranteeing the quality of firms' financial statements that affect the success of stakeholders' decision making. Greater quality of their financial statements is possibly related to more successful decision making. Thus, abilities, competencies, and capabilities of auditors are important and they can enhance them to achieve professional success in auditing works according to auditing and professional standards,

${ }^{1}$ First Author and Corresponding Author. Associate Professor, Faculty of Management Sciences and Information Technology, Nakhon Phanom University, Thailand [Postal Address: Nai Mueang, Mueang Nakhon Phanom District, Nakhon Phanom 48000, Thailand]

Email: kornchai.p@npu.ac.th

${ }^{2}$ Assistant Professor, Faculty of Management Sciences and Information Technology, Nakhon Phanom University, Thailand.

Email: khajit.nk@npu.ac.th

(c) Copyright: The Author(s)

This is an Open Access article distributed under the terms of the Creative Commons Attribution Non-Commercial License (https://creativecommons.org/licenses/by-nc/4.0/) which permits unrestricted non-commercial use, distribution, and reproduction in any medium, provided the original work is properly cited. namely audit practices, functions, duties, activities, and responsibilities. To increase great professional success, auditors need to search for a way of building, creating and improving their audit works. In the existing literature, audit socialization is one source of auditors' success, survival and sustainability in the auditing profession. It plays a significant role in driving, explaining and enlarging auditors' superior long-term success. Here, audit socialization refers to the lengthy and ongoing process by which auditors are instilled with professional values and learn about proper work practices through values, abilities, expected behaviors, and social knowledge (Lui, Ngo, \& Tsang, 2003). Audit socialization is essential as auditors should play a professional role and participate in their community as professional members. Audit socialization enhances auditors to provide a longterm commitment, achieve a successful performance and behave an undesired turnover in the auditing profession. Effective audit socialization inspires auditors to think and act in accordance with professional interests. Well-socialized auditors are likely to be committed to auditing profession, willing and able to act effectively on their behalf and are less likely to initiate a departure (Fogarty, 2000). Accordingly, they tend to provide more professional commitment and achieve superior professional success. 
Interestingly, professional commitment is an important consequence of auditors' concerns with audit socialization and it is defined as the attachments that individuals form to their profession (Elias, 2006). It promotes auditors to believe and accept the goals of the profession. Auditors with more professional commitment tend to have a greater willingness to provide important attempts on behalf of the profession and save themselves with longer memberships in the profession. They are likely to act good practices, duties, functions, and activities in audit works that potentially influence their performance and success. Also, professional success refers to auditors' job performance, namely efficiency, effectiveness, quality, and goal achievement of audit works in long-term practices (Wier, Stone, \& Hunton, 2005). More audit socialization and better professional commitment positively relate to superior professional success. Thus, auditors with greater audit socialization and more professional commitment tend to have a better audit success. Likewise, individual learning is defined as knowledge acquisition, skills and competencies that contribute to individual development and raise a deeper understanding of oneself as increasingly connected to others (Williams \& Castro, 2010). In rapidly changing environments, individual learning can help auditors seek new knowledge and use existing knowledge to unleash the innovative potential in audit works. Therefore, individual learning is proposed to become a moderator of the aforementioned research relationships.

In Thailand, there are two auditing professions, namely certified public accountants and tax auditors. While much previous research has investigated the characteristics, qualifications, practices, and behaviors of certified public accountants, this study focuses on tax auditors. Tax auditors are approved by the Department of Revenue, Ministry of Finance and have functions, duties and responsibilities similar to certified public accountants, but they investigate and certify financial statements of only registered partnerships. Also, the number of tax auditors has continuously increased from passing qualifying knowledge examinations of accounting, auditing, revenue codes, and civil and commercial codes relating to registered partnerships. Thus, tax auditors are appropriate samples of the study because this study can offer different contributions and implications to existing auditing literature.

Here, this study aims at investigating the effects of audit socialization on professional commitment and professional success of tax auditors in Thailand through a moderating influence of individual learning. In this study, the key research question is how audit socialization leads to professional success? The specific research questions are: (1) How audit socialization affects professional commitment, (2) How professional commitment influences professional success, and (3) How individual learning moderates the audit socialization-professional commitment relationships, the audit socialization-professional success relationships, and the professional commitment-professional success relationships.

\section{Literature Review and Hypotheses Development}

\subsection{Professional Success}

Professional success is a valuable outcome of concerning audit socialization and professional commitment. It refers to auditors' job performance, namely efficiency, effectiveness, quality, and goal achievement of audit works in longterm practices (Wier, Stone, \& Hunton, 2005). It reflects the abilities, competencies and capabilities of auditors in providing the practices, duties, functions, activities, and responsibilities of audit works effectively, efficiently and excellently according to auditing and professional standards. The acceptance, reliability and credibility of auditors are also measured as a success of their audit works. Thus, potential professional success results from auditors' socialization and commitment in their professional works. In this study, great audit socialization positively relates to superior professional success while potential professional commitment positively leads to professional success. Then, auditors with greater audit socialization and more professional commitment tend to have a better audit success.

\subsection{Audit Socialization}

In the existing literature, organizational socialization is the process through which newcomers learn the requisite social and task knowledge to resolve role ambiguity, role uncertainty and role conflict, enhance role definition and role clarity, and become organizational insiders (Rao Kowtha, 2018). The newcomers' successful organizational socialization is likely to have better retention, higher productivity, greater job satisfaction and loyalty, and reduced recruitment and training costs. Also, organizational socialization can create mechanisms for information communication to reduce employees' uncertainty and increase their perceptions of career security (Kennedy \& Widener, 2019). Thus, firms focusing on organizational socialization mechanism tend to directly create and maintain their employees' productivity, satisfaction and loyalty and indirectly promote their organizational success, survival and sustainability, Similarly, professional socialization is the process by which persons acquire knowledge, skills and disposition that make them more or less effective members of society (Page, 2005). It becomes a subconscious process whereby they internalize behavioral norms and standards and form a sense of identity and commitment to a professional field. While professional socialization matters, it undergoes through professional education during their schooling and related work experiences. Accordingly, professional socialization is the acquisition of reference values, attitudes, skills, and knowledge pertaining to 
Kornchai PHORNLAPHATRACHAKORN, Khajit NA KALASINDHU /

a professional subculture. It explicitly promotes value clarification, professional identity and career fulfilment in a profession (Anderson-Gough, 2018). Thus, professional socialization is likely to have a significant positive effect on professional performance and success in the present and future aspects. In summary, both organizational socialization and professional socialization can make the differences and similarities of benefits and advantages to organizations and professional works (McClaren, Adam, \& Vocino, 2010). They are important for enhancing professions' success, survival and sustainability in their professional life.

Professional socialization explicitly matters for several fields, such as nursing, law, pharmacy, education, engineering, accountancy, and business. It has enhanced persons who have careers in these fields in order to achieve, gain and receive professional commitment, success, survival, and sustainability. Great professional socialization is likely to have a significant relationship with superior goal achievement in their careers. In the existing literature of accounting and auditing, professional socialization plays an important role in driving, determining and explaining accountants, auditors and related professions' successes in the present and future practices and in the long-term aspect. It is the internalization of the norms and behaviors of their professions. Professional socialization among accountants has increased job satisfaction, decreased entry shock, decreased job turnover, and increased ethical awareness and behavior (O'Brien, 2018). Accountants with strengthened professional socialization tend to have best accounting practices and achieve great professional success. Similarly, auditors who are aware of professional socialization are likely to have a belief in and acceptance of the goals and values of the profession, a willingness to exert considerable effort on behalf of the profession, and a desire to maintain membership in the profession (Herda \& Martin, 2016). They can create and enhance professional commitment through the dedication to a professional career, identification with the profession, and acceptance of the profession's goals and ethics. More professional commitment potentially affects greater professional success.

In this study, professional socialization in the auditing profession has potentially considered as the key factor of professional success. This professional socialization is referred as audit socialization. In audit works, audit socialization plays a significant role in driving and explaining audit performance and outcome and it is a key determinant of professional commitment and professional success. Audit socialization is defined as a process by which auditors come to learn and understand the values, abilities, expected behaviors, and social knowledge that are essential for assuming a professional role and for participating a professional member (Elias, 2007). It emphasizes the acquisition of the values, skills and knowledge of a professional subculture and the adoption of attitudes and beliefs of obtaining auditing professions' membership. It explicitly enhances auditors to develop an inclination to use skills in audit practices, to appreciate the challenge in audit works and to resolve demands for varying types of the audit duties and functions. Thus, well-socialized auditors tend to provide and act professionally according to auditing and professional standards and regulations and achieve and gain the efficiency, effectiveness, quality, and excellence of their audit works in long-term aspects. They are more likely to be committed to the auditing profession, willing and able to act effectively on their own behalf, and less likely to initiate a departure (Fogarty, 2000). Accordingly, auditors who are joining an auditing profession must learn the attitudes, values, beliefs, and behaviors of the professional culture that they are joining. Auditors with great socialization are likely to have long-term professional commitment, superior professional performance, success and outcome and undesired turnover.

In addition, audit socialization refers to the lengthy and ongoing process by which auditors are instilled with professional values and learn about proper work practices (Lui, Ngo, \& Tsang, 2003). It encourages auditors to be admitted into auditing professions through acquiring knowledge, acting independently, accepting status, and providing help. Auditors with effective socialization are likely to think and act in accordance with professional interests. Greater audit socialization definitely promotes auditors to be committed with auditing professions through believing and accepting the goals of the professions and being willing to exert significant efforts on behalf of the profession (Elias, 2008). Audit socialization results from both formal and informal pressures exerted on members of auditing profession by other professional members through role modeling and mentoring upon whom they are dependent and by cultural expectations from within the professional society (Siegel, Agrawal, \& Rigsby, 1997). It provides the collective struggle of auditors to define the conditions and methods of their works, to control the supply of procedures and to establish legitimation for their professional autonomy. It potentially influences auditors to have successfully acted and excellently worked with professional practices, duties and functions. It is essential to drive and determine and it explains auditors' success within rapidly changing environments, conditions and situations. Thus, audit socialization is positively related to increased professional commitment, improved work performance, reduced turnover intention, greater job satisfaction, and professional success. It is positively related to stronger professional commitment and better professional success. Therefore,

H1: Audit socialization is positively related to (a) professional commitment and (b) professional success. 


\subsection{Professional Commitment}

Here, professional commitment exists as a result of audit socialization process in audit works and it is an effective outcome of concerning audit socialization and it is defined as a strong belief in and acceptance of the goals and values of the profession, readiness and a willingness to exert considerable effort on behalf of the profession and a strong desire to remain and maintain membership in the profession (Herda \& Martin, 2016). High professional commitment explicitly orients auditors toward behaviors that comply with the accounting and professional standards and the public interests and away from behaviors that have the potential to damage the profession. Auditors with great professional commitment tend to have superior performance, outcome and success in their audit works. Thus, professional commitment is positively related to their professional success. Also, professional commitment refers to the attachments that individuals form to their profession in terms of their strong identification with, investment in and loyalty to the professional group (McManus \& Subramaniam, 2014). It is critical as it reduces the likelihood of leaving the profession, improves job satisfaction and improves the quality of work performance (Dong \& Phuong, 2018; Nguyen \& Ngo, 2020). Professional commitment continuously enhances auditors to be concerned with the auditing profession, provide the excellence of auditing professional services and focus on the long-term sustainability of the profession. More committed professionals are likely to create best work behaviors, such as rule observance attitudes, sign-off judgments, involvement in professional auditing associations, and propensity to mentor junior auditors. Accordingly, professional commitment potentially drives auditors to provide best audit practices and achieve long-term success in their audit works.

Professional commitment comprises affective professional commitment, continuance professional commitment and normative professional commitment. Firstly, effective professional commitment is the extent to which individuals want to stay in the profession because they identify with the profession's goals and want to help their clients to achieve goals (Smith \& Hall, 2008). Secondly, continuance professional commitment is the extent to which individuals feel they have to stay in the profession and can result from positive or negative exchanges and experiences (Choi, 2020; Hall, Smith, \& Langfield-Smith 2005). Lastly, normative professional commitment is the extent to which individuals believe they ought to stay in the profession through a sense of obligation (Greenfield, Norman, \& Wier, 2008). In auditing literature, professional commitment enhances auditors to acknowledge and trust the values and objectives of a profession, be willing to exercise substantial efforts on behalf of the profession and involve in an explicit goal to remain a member of the profession. It can potentially encourage auditors to behave well and provide appropriate activities in audit works, do excellent audit practices, functions, duties, and responsibilities in professional life and achieve and gain successful audit performance and outcome in the future and the long term. According to the aforementioned discussion, professional commitment is likely to have an important influence on auditors' professional success. It is positively related to professional success. Therefore,

H2: Professional commitment is positively related to professional success.

\subsection{Individual Learning}

Individual learning plays a significant role in moderating those relationships and it is proposed to become a moderator of the relationships. Individual learning is an essential foundation of professional life in auditing profession. It is defined as activities in which individuals seek to acquire, share, refine, or combine knowledge through interaction with one another (Dayaram \& Fung, 2014). It can help seek new knowledge and use existing knowledge to unleash innovative potential and build valuable outcomes and performance in rapidly changing environments. In addition, individual learning refers to knowledge acquisition, skills and competencies that contribute to individual development and raise a deeper understanding of oneself as increasingly connected to others (Williams \& Castro, 2010). It entails the solitary act of exploration through a person coming upon a serendipitous discovery of his or her own without any external influence (Chang \& Harrington, 2013). Great individual learning is likely to affect success in job practices, duties, functions, activities, and responsibilities. In auditing literature, auditors with individual learning are aware of their knowledge and make this tacit knowledge explicit through allowing knowledge to be shared between individuals and this becomes an increasingly collective knowledge activity. Thus, individual learning enhances to succeed in the auditing professions.

In addition, individual learning reasonably relates to an individual's increasing job satisfaction and improving performance in a professional life. Individual learning takes place when new knowledge is acquired as a result of the transformation of existing experiences and potential observations (Stelmaszczyk, 2016). It is placed among cognitive processes, namely intuiting and interpreting processes with the selective retention of experiences by involving the usage of various mechanisms through utilizing own experiences and using valuable observations. Also, individuals can take more responsibility for their own learning and gain a sequence of the connection between training and work environments (Magni, Paolino, Cappetta, \& Proserpio, 2013). They attempt to satisfy the increasing demand for active and involving experiences and trainings. Individual learning can also occur via experience and training. Experience is an interactive and complex process involving several kinds of opportunity for practice and environment, including a positive organizational environment while training is a linear process of learning and application on the part of the trainee (Johnson \& Thomas, 2007). 


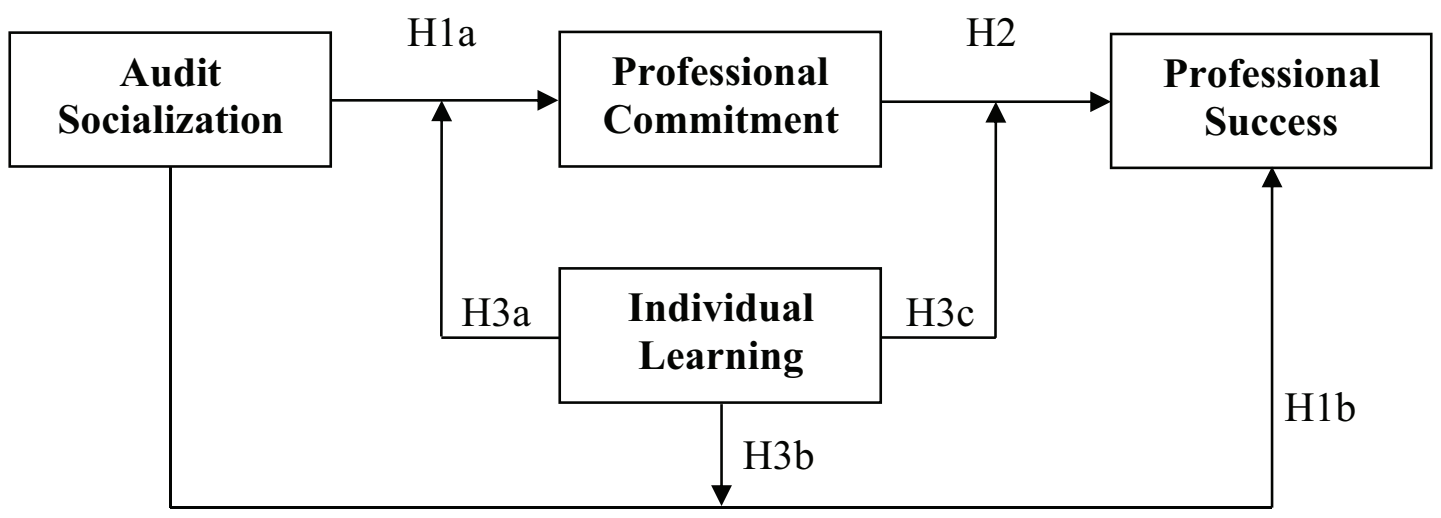

Figure 1: The conceptual model of the audit socialization-professional success relationships

Thus, individual learning is an effective learning process that needs to take existing experience and valuable training into account and build on them. Auditors with efficient individual learning are likely to have great commitment in auditing profession and achieve professional success in audit works. In this study, individual learning is proposed to become a moderator of the research relationships. It positively moderates the audit socialization-professional commitment relationships, the audit socialization-professional success relationships and the professional commitment-professional success relationships. Therefore,

H3: Individual learning positively moderates (a) the audit socialization-professional commitment relationships, (b) the audit socialization-professional success relationships and (c) the professional commitment-professional success relationships.

As mentioned earlier, audit socialization becomes a main determinant of professional commitment and professional success. Thus, the research relationships of these variables are discussed and hypothesized earlier. The conceptual model presents the aforementioned relationships, as shown in Figure 1.

\section{Research Methods}

\subsection{Sample Selection Procedure and Data Collection}

Here, tax auditors in Thailand are the key informants of the study and the samples of the study and they investigate and certify financial statements of only registered partnerships. Thus, 1,000 tax auditors are appropriate samples of the study because this study can offer different contributions and implications to existing auditing literature. Regarding to the questionnaire mailing, the valid mailing was 972 surveys, from which 253 responses were received. Of the surveys completed and returned, 249 surveys were usable. The effective response rate was approximately $25.62 \%$. The response rate for a mail survey, with an appropriate follow-up procedure, if greater than $20 \%$ is considered acceptable according to Aaker, Kumar, and Day (2001).

\subsection{Test of Non-Response Bias}

In surveys, non-response is considered a source of possible bias, which increases with the size of the nonresponding group. To verify and test potential nonresponse bias and to detect and protect possible problems with non-response errors, a comparison of the first and the second wave data as recommended by Armstrong and Overton (1977) is used. In this study, gender (GD), age (AG), educational level (ED), and audit work experience (AE) are considered as the variables for testing the nonresponse bias. Also, t-test statistic is utilized to verify the differences of the variables. In this regard, neither procedure showed significant differences because there were no statistically significant differences between first and second groups at a $95 \%$ confidence level as gender $(\mathrm{t}=0.143, \mathrm{p}>.05)$, age $(\mathrm{t}=0.124, \mathrm{p}>.05)$, education level $(\mathrm{t}=0.131, \mathrm{p}>.05)$, and audit work experience $(\mathrm{t}=0.113$, $\mathrm{p}>.05)$ respectively.

\subsection{Measures}

All constructs were measured using a 5-point Likert scale $(1=$ strongly disagree to $5=$ strongly agree $)$, except for gender, age, educational level, and audit work experience. Measurements of these constructs are self-developed from existing literature as shown in Appendix A. 


\subsubsection{Audit Socialization}

Audit socialization is the independent variable of the study. Seven-item scale was developed to assess how auditors acquire the values, skills and knowledge of a professional subculture and adopt the attitudes and beliefs of obtaining auditing professions' membership.

\subsubsection{Professional Commitment}

Professional commitment is the mediating variable of the study. Seven-item scale was established to measure how auditors orient toward behaviors that are form to their profession in terms of their strong identification with, investment in and loyalty to the professional group.

\subsubsection{Individual Learning}

Individual learning is the moderating variable of the study. Five-item scale was initialed to evaluate how auditors provide knowledge acquisition, skills and competencies that contribute to individual development and raise a deeper understanding of oneself as increasingly connected to others.

\subsubsection{Professional Success}

Professional success is the dependent variable of the study. Six-item scale was developed to gauge how auditors achieve the outcomes and performance of audit works according to auditing and professional standards and survival and sustainability of their audit practices.

\subsubsection{Control Variables}

Here, gender, age, educational level, and audit work experience are the control variable of the study. Gender (GD) was measured by using a dummy variable as male $=0$ and female $=1$. Also, age $(\mathrm{AG})$ was measured by the length of time that an auditor has lived by using a dummy variable as less than 30 years $=0$ and equal to or greater than 30 years $=1$. Similarly, educational level (ED) was measured by the level of education that an auditor has graduated by using a dummy variable as a bachelor degree or equivalence $=0$ and higher bachelor degree $=1$. Finally, audit work experience $(\mathrm{AE})$ was measured by the length of time that an auditor has worked in the audit jobs and related activities by using a dummy variable as less than 10 years $=0$ and equal to or greater than 10 years $=1$.

\subsection{Methods}

\subsubsection{Validity and Reliability}

This study conducts confirmatory factor analysis to examine the discriminant validity of the variables at the individual level, namely audit socialization, professional commitment, individual learning, and professional success (Peng, Chen, Xia, \& Ran, 2017). The confirmatory factor analysis was implemented to assess the underlying relationships of a large number of items and to determine whether they can be reduced to a smaller set of factors. All factor loadings as values of $0.72-0.90$ are greater than the 0.40 cut-off and are statistically significant (Nunnally \& Bernstein, 1994). Thus, this study concludes that the four variables of the study are empirically distinct from each other, representing four distinct constructs.

The discriminant power is implemented for identifying the nature of the discrimination for each discriminant function by looking at the means for the functions across groups. It was utilized to gauge the validity of the measurements by item-total correlation. In the scale validity, item-total correlations as values of 0.72 0.90 are greater than 0.30 (Churchill, 1979). Then, all measurements of the four variables are valid and they are appropriately used for testing the research relationships and hypotheses.

Lastly, the reliability of the measurements focuses on a measure of internal consistency that is how closely related a set of items are as a group. Cronbach alpha is the most common measure of internal consistency ( $\mathrm{Mu}$, Thomas, Peng, \& Benedetto, 2017). It is most commonly used when researchers have multiple Likert questions in a survey/ questionnaire that form a scale and you wish to determine if the scale is reliable. In the scale reliability, Cronbach alpha coefficients as values of $0.86-0.92$ are greater than 0.70 (Nunnally \& Bernstein, 1994). Accordingly, the scales of all measures express an acceptable validity and reliability in this study. Table 1 presents the results for factor loadings, item-total correlation and Cronbach alpha for multiple-item scales used in this study.

Table 1: Results of measure validation

\begin{tabular}{|l|c|c|c|}
\hline Items & $\begin{array}{c}\text { Factor } \\
\text { Loadings }\end{array}$ & $\begin{array}{c}\text { Item-total } \\
\text { Correlation }\end{array}$ & $\begin{array}{c}\text { Cronbach } \\
\text { Alpha }\end{array}$ \\
\hline $\begin{array}{l}\text { Audit } \\
\text { socialization } \\
\text { (AS) }\end{array}$ & $0.77-0.89$ & $0.77-0.88$ & 0.90 \\
\hline $\begin{array}{l}\text { Professional } \\
\text { commitment } \\
\text { (PC) }\end{array}$ & $0.72-0.84$ & $0.72-0.84$ & 0.90 \\
\hline $\begin{array}{l}\text { Individual } \\
\text { learning (IL) }\end{array}$ & $0.78-0.87$ & $0.78-0.86$ & 0.86 \\
\hline $\begin{array}{l}\text { Professional } \\
\text { success (PS) }\end{array}$ & $0.76-0.90$ & $0.76-0.90$ & 0.92 \\
\hline
\end{tabular}




\subsubsection{Statistical Techniques}

This study investigates the research relationships of tax auditors in Thailand. Structural equation model (SEM) is utilized for data analysis and it is considered as an appropriate method to test the relationships of these variables. This method fits the composite method and it is also the safest option when estimating data from unknown population (Kianto, Saenz, \& Aramburu, 2017). In addition, multiple regression analysis is applied to test the direct, indirect and moderating effects of the research relationships (Montani, Courcy, \& Vandenberghe, 2017). It can help verify the moderating effects of individual learning on the aforementioned research relationships. Thus, multiple regression analysis has potential for testing the research relationships.

\section{Results and Discussion}

\subsection{Descriptive Statistics and Correlation Matrix}

Table 2 presents the descriptive statistics and correlation matrix for all variables. Multicollinearity might occur when inter-correlation in each predictor variable is more than 0.80 , which is a high relationship (Hair, Black, Babin, \& Anderson, 2010). The correlations ranging from 0.61 to 0.68 , which means that the possible relationships of the variables in the conceptual model could be tested.
Thus, there are no substantial multicollinearity problems encountered in this study. To confirm no multicollinearity problems in this study, variance inflation factors (VIF) is considered as an approach for the detection of high correlations between multiple independents in the equation. Here, the VIF scores can indicate ranging from 3.17 to 4.56 , which means that multicollinearity is not a serious problem in a regression analysis if the VIF score is lower than 10 on the scales.

\subsection{Results of the Research Relationships and Hypotheses}

Tables 3 and 4 present the results of path coefficients and hypotheses testing of the research relationships. The moderating effects of the study are also presented in Table 4. A summary of the audit socialization-professional success relationships is shown in Figure 2. In this study, the goodness of fit of the models, including the goodness of fit index (GFI), the comparative fit index (CFI), the incremental fit index (IFI), and the root mean square error of approximation (RMSEA) are considered (Herda \& Lavelle, 2012). Firstly, CFI values always lie between 0 and 1, with values over 0.90 indicating a relatively good fit (Bentler, 1990). This study shows the values of CFI as 0.93. Secondly, GFI value is an index that ranges from 0 to 1 , with a value over 0.90 indicating a relatively good fit (Byrne, 1998). Here, the value of GFI is 0.92.

Table 2: Descriptive statistics and correlation matrix

\begin{tabular}{|c|c|c|c|c|}
\hline Variables & AS & PC & IL & PS \\
\hline Mean & 3.94 & 3.98 & 4.00 & 3.84 \\
\hline Standard deviation & 0.14 & 0.24 & 0.17 & 0.69 \\
\hline \multicolumn{5}{|l|}{ Audit socialization (AS) } \\
\hline Professional commitment (PC) & $0.65^{\star * *}$ & & & \\
\hline Individual learning (IL) & $0.64^{* * *}$ & $0.65^{* * *}$ & & \\
\hline Professional success (PS) & $0.61^{* * *}$ & $0.64^{* * *}$ & $0.68^{* * *}$ & \\
\hline
\end{tabular}

${ }^{* * *} p<.01$

Table 3: Results of path coefficients and hypotheses testing ${ }^{1}$

\begin{tabular}{|l|c|c|c|c|c|}
\hline Hypotheses & Relationships & Coefficients & $\begin{array}{c}\text { Standard } \\
\text { Error }\end{array}$ & t-value & Results \\
\hline $\mathrm{H} 1 \mathrm{a}$ & $\mathrm{AS} \rightarrow \mathrm{PC}$ & $0.66^{* * *}$ & 0.11 & 6.14 & Supported \\
\hline $\mathrm{H} 1 \mathrm{~b}$ & $\mathrm{AS} \rightarrow \mathrm{PS}$ & $0.24^{* * *}$ & 0.09 & 2.58 & Supported \\
\hline $\mathrm{H} 2$ & $\mathrm{PC} \rightarrow \mathrm{PS}$ & $0.64^{* * *}$ & 0.13 & 4.80 & Supported \\
\hline
\end{tabular}

${ }^{* * *} \mathrm{p}<.01 ; \mathrm{CFI}=0.93 ; \mathrm{GFI}=0.92 ; \mathrm{IFI}=0.94 ; \mathrm{RMSEA}=0.04$

${ }^{1} \mathrm{AS}=$ Audit Socialization; $\mathrm{PC}=$ Professional Commitment; $\mathrm{PS}=$ Professional Success 
Table 4: Results of multiple regression analysis ${ }^{\mathrm{a}, 2}$

\begin{tabular}{|c|c|c|c|c|c|c|}
\hline \multirow{2}{*}{$\begin{array}{l}\text { Independent } \\
\text { Variables }\end{array}$} & \multicolumn{6}{|c|}{ Dependent variables } \\
\hline & PC & PC & PS & PS & PS & PS \\
\hline \multirow[t]{2}{*}{ AS } & $0.74^{\star \star \star}$ & 0.42 & $0.82^{\star \star \star}$ & 0.45 & & \\
\hline & $(0.07)$ & $(0.14)$ & $(0.08)$ & $(0.17)$ & & \\
\hline \multirow[t]{2}{*}{$\mathrm{PC}$} & & & & & $0.84^{* \star *}$ & $1.57^{* * *}$ \\
\hline & & & & & $(0.07)$ & $(0.16)$ \\
\hline \multirow[t]{2}{*}{$\mathrm{IL}$} & & 0.20 & & 0.21 & & $1.74^{* * *}$ \\
\hline & & $(0.13)$ & & $(0.10)$ & & $(0.11)$ \\
\hline \multirow[t]{2}{*}{$A S^{*} I L$} & & 0.02 & & 0.03 & & \\
\hline & & $(0.14)$ & & $(0.16)$ & & \\
\hline \multirow[t]{2}{*}{$P C^{*} I L$} & & & & & & $0.50^{* * *}$ \\
\hline & & & & & & $(0.14)$ \\
\hline \multirow[t]{2}{*}{ GD } & 0.06 & 0.05 & 0.06 & 0.05 & 0.04 & 0.04 \\
\hline & $(0.06)$ & $(0.06)$ & $(0.07)$ & $(0.07)$ & $(0.07)$ & $(0.06)$ \\
\hline \multirow[t]{2}{*}{$A G$} & -0.02 & -0.02 & -0.01 & -0.01 & 0.02 & 0.01 \\
\hline & $(0.09)$ & $(0.09)$ & $(0.10)$ & $(0.10)$ & $(0.09)$ & $(0.09)$ \\
\hline \multirow[t]{2}{*}{ ED } & -0.09 & -0.10 & -0.02 & -0.03 & 0.06 & 0.01 \\
\hline & $(0.07)$ & $(0.07)$ & $(0.08)$ & $(0.08)$ & $(0.08)$ & $(0.07)$ \\
\hline \multirow[t]{2}{*}{$\mathrm{AE}$} & 0.05 & 0.06 & 0.08 & 0.04 & 0.09 & 0.03 \\
\hline & $(0.01)$ & $(0.02)$ & $(0.03)$ & $(0.01)$ & $(0.05)$ & $(0.01)$ \\
\hline Adjusted $\mathrm{R}^{2}$ & 0.47 & 0.48 & 0.44 & 0.45 & 0.54 & 0.61 \\
\hline
\end{tabular}

${ }^{* * *} p<.01$, a Beta coefficients with standard errors in parenthesis.

${ }^{2} \mathrm{AS}=$ Audit Socialization; $\mathrm{PC}=$ Professional Commitment; IL = Individual Learning; PS = Professional Success; GD = Gender; $A G=$ Age; $E D=$ Education Level; $A E=$ Work Experience

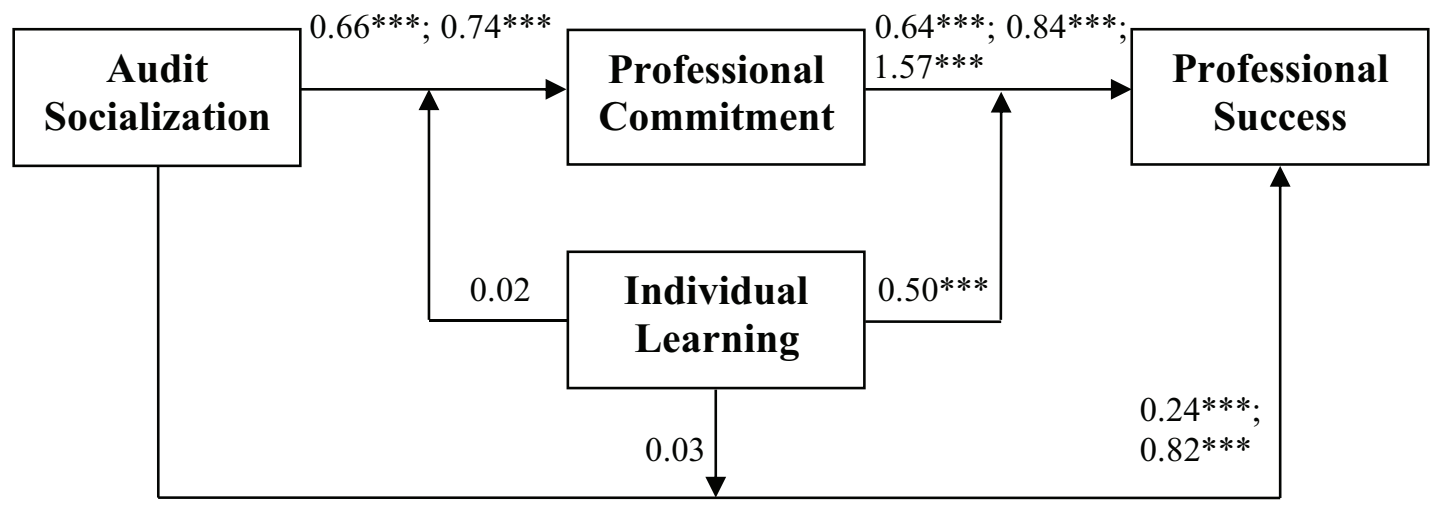

$* * * \mathrm{p}<.01$

Figure 2: A summary of the audit socialization-professional success relationships 
Kornchai PHORNLAPHATRACHAKORN, Khajit NA KALASINDHU /

Thirdly, IFI values exceeding 0.90 indicate a relatively good fit (Kline, 1998). The results of this study present the values of IFI as 0.94. Lastly, a RMSEA value of less than 0.05 indicates a close fit and less than 0.08 suggests a marginal fit (Bollen \& Long, 1993). The RMSEA value is 0.04 . In summary, this study shows that the initial test of the measurement model resulted in a good fit to the data.

To test the effects of audit socialization on professional commitment and professional success, the results shows that audit socialization is positively related to professional commitment $(b=0.66, p<0.01 ; b=0.74, p<0.01)$ and professional success $(b=0.24, p<0.01 ; b=0.82, p<0.01)$. Consistent with existing literature, audit socialization plays a significant role in defining, determining, driving, and explaining auditors' job performance and outcomes, namely professional commitment and professional success. According to a study of Elias (2007), audit socialization encourages auditors to provide the acquisition of the values, skills and knowledge of a professional subculture and the adoption of attitudes and beliefs of obtaining auditing professions' membership through developing an inclination to use skills in the audit practices, appreciating the challenge in the audit works and resolving demands for varying types of the audit duties and functions. Auditors with great socialization can be committed to the auditing profession, willing and able to act effectively on its behalf, and less likely to initiate a departure (Fogarty, 2000). Also, audit socialization influences auditors to have successfully acted and excellently worked with professional practices, duties and functions. Thus, well-socialized auditors tend to have potential professional commitment, superior professional performance, success and outcome, and undesired turnover. Therefore, Hypotheses 1a-1b are supported.

Similarly, the relationships between professional commitment and professional success are empirically examined. Professional commitment has a significant positive effect on professional success $(b=0.64, p<0.01 ; b=0.84, p<0.01 ; b=$ $1.57, \mathrm{p}<0.01)$. It explicitly relates to improved and increased the survival and sustainability of professional success in long-term aspects. In existing literature, professional commitment is a strong belief in and acceptance of the goals and values of the profession, a readiness and a willingness to exert considerable effort on behalf of the profession and a strong desire to remain and maintain membership in the profession (Herda \& Martin, 2016). It is critical to link to reduced likelihood of leaving the profession, improved job satisfaction and improved the quality of work performance. Auditors with great professional commitment are explicit concerns with auditing profession, the excellence of auditing professional services and long-term sustainability of the profession. More committed auditors can provide best audit practices and achieve a success of their audit works. Thus, professional commitment is positively related to auditors' superior and long-term outcomes, performance and success in audit professions within rapidly environmental changes and situations. Therefore, Hypothesis 2 is supported.

Verifying the moderating effects of the research relationships, individual learning is an important moderator of the professional commitment-professional success relationships. It positively moderates the aforementioned relationships $(b=0.50, p<0.01)$. In this study, individual learning emphasizes knowledge acquisition, skills and competencies through a result of the transformation of existing experiences and potential observations that contribute to individual development and raise a deeper understanding of oneself as increasingly connected to others (Williams \& Castro, 2010). Auditors with the best individual learning are aware of their knowledge and make this tacit knowledge explicit by allowing knowledge to be shared between individuals and becoming an increasingly collective knowledge activity. They can achieve success in job practices, duties, functions, activities, and responsibilities. Accordingly, individual learning can lead to auditors' success in audit works and professions. It has a positive moderating effect on professional commitmentprofessional success relationships. Therefore, Hypothesis $3 \mathrm{c}$ is supported.

Surprisingly, individual learning does not moderate the audit socialization-professional commitment relationships $(b=0.02, p<0.88)$ and the audit socialization-professional success relationships $(b=0.03, p<0.86)$. According to existing literature, the relationships between audit socialization and professional commitment are explicitly verified and strongly confirmed. Audit socialization is definitely related to professional commitment (Elias, 2007). Thus, even though individual learning is important, it may not strengthen the audit socialization-professional commitment relationships. Then, individual learning is not a moderator of the aforementioned relationships. Likewise, individual learning is not a moderator of the audit socializationprofessional success relationships. Audit socialization can potentially enhance auditors to achieve the survival and sustainability of professional performance, success and outcome in audit works (Fogarty, 2000). Similarly, auditors who are aware of professional socialization are likely to have a belief in and acceptance of the goals and values of the profession, a willingness to exert considerable effort on behalf of the profession, and a desire to maintain membership in the profession (Herda \& Martin, 2016). Accordingly, audit socialization tends to directly have a significant influence on professional commitment and professionalism respectively. Thus, the audit socialization-professional commitment relationships and the audit socialization-professional success relationships do not need to have a moderator in order to strengthen the aforementioned research relationships. Hence, individual learning may not drive the stronger relationships of those variables. Therefore, Hypotheses $3 b-3 b$ are not supported. 
Interestingly, both structural equation model and multiple regression analysis are applied to examine the research relationships. They are beneficial to test the research relationships. This study shows the similar research results of the relationships according to the aforementioned discussions and explanations. Congruent with Alavifar, Karimimalayer, and Anuar (2012)'s study, structural equation model is a powerful multi-variables analytical technique from multivariables regression family or extension of general linear modeling which enables to examine some set of regression equations simultaneously.

\section{Contributions and Limitations}

\subsection{Theoretical Contribution}

This study confirms the values of audit socialization in audit works. Audit socialization plays a significant role in driving, determining and explaining the commitment and success of auditing professions. The relationships among audit socialization, professional commitment and professional success are empirically confirmed. Likewise, individual learning can help strengthen the relationships between professional commitment and professional success. While this study investigates the effects of overall audit socialization on professional success, future research may do more literature reviews relating to audit socialization and classify its concepts into each dimension and component of audit socialization. An empirical investigation is also considered for future research. In addition, to expand the current study and increase the generalizability of the study, future research may collect data from larger samples of the study and other auditing professions, namely certified public accountants (CPA), governmental auditors (GA) and cooperative auditors (CA) in order to verify the research results.

\subsection{Professional Contribution}

According to the research results, auditors must be concerned with the importance, necessity, and role of audit socialization in audit works. They need to focus on studying, learning and understanding the characteristics of audit socialization and applying and implementing it to audit jobs according to auditing and professional standards. Auditors' abilities, competencies and capabilities can help effectively utilize the socialization of audit works, efficiently work and practice their audit duties, functions, activities, and responsibilities and gain the success, survival and sustainability of their professional life. Greater audit socialization is critically related to more success in auditing professional jobs. Thus, auditors need to pay attention to improving, developing and increasing the concepts of audit socialization and utilizing it to audit works.

\subsection{Limitations}

In this study, there are some limitations of the study, including the similar concepts between audit socialization and individual learning and the little number of usable responses. Firstly, audit socialization is the process by which auditors come to learn and understand the values, abilities, expected behaviors, and social knowledge that is essential for assuming a professional role and for participating a professional member (Elias, 2007), while individual learning is the knowledge acquisition, skills and competencies that contribute to individual development and raise a deeper understanding of oneself as increasingly connected to others (Williams \& Castro, 2010). The definitions of the two constructs are very closely. Accordingly, this reason may make individual learning that is not a moderator of the audit socialization-professional commitment relationships and the audit socialization-professional success relationships are moderated from individual learning. Thus, future research may need to do more literature review and re-conceptualize the research relationships. It may check the existing literature deeply in order to create differences between audit socialization and individual learning. Likewise, other moderators may need to put in the conceptual model to add more contributions for the current study, such as stakeholder expectation, environmental pressure, technology force, and audit experience. Secondly, even though the number of usable responses as 249 surveys is acceptable, these surveys can create little power of tests. The results of the study, especially the moderator of the study show that there are no effects on the research relationships. Thus, future research may expand more timing of data collection. Also, future research may select an effective period of a year for doing data collection as June to December to increase the number of usable responses and the response rate of the study.

\section{Conclusion}

This study aims at investing the relationships among audit socialization, professional commitment, individual learning, and professional success of tax auditors in Thailand. In this study, audit socialization is the independent variables; professional commitment is the mediating variable; individual learning is the moderating variable; and professional success is the dependent variable. Here, 249 tax auditors in Thailand collected data by using the questionnaire were the samples of the study. Both structural equation model and multiple regression analysis are considered to the research relationships. The results indicate that audit socialization positively relates to professional commitment and it positively leads to professional success. Also, professional commitment is positively linked to professional success. To test the moderating effects of the research 
relationships, individual learning is the moderator of the professional commitment-professional success relationships. Inversely, individual learning does not moderate the audit socialization-professional commitment relationships and the audit socialization-professional success relationships.

In summary, audit socialization is a key determinant of both professional commitment and professional success in audit works. Accordingly, auditors should pay attention to study, learn and understand the characteristics of audit socialization and apply and implement it to audit jobs according to auditing and professional standards. To verify and expand the current study, future research may need to do more literature review and re-conceptualize the research relationships relating to audit socialization and its concepts, dimensions and components, and individual learning and its importance, necessaries and roles. Also, future research may focus on collected data from larger samples of the study and other auditing professions, namely certified public accountants (CPA), governmental auditors (GA) and cooperative auditors (CA) in order to verify the research results.

\section{References}

Aaker, D. A., Kumar, V., \& Day, G. S. (2001). Marketing research. Hoboken NJ: John Wiley and Sons.

Anderson-Gough, F. (2018). Making up accountants: the organizational and professional socialization of trainee chartered accountants. Abingdon, UK: Routledge.

Alavifar, A., Karimimalayer, M., \& Anuar, M. K. (2012). Structural equation modeling vs multiple regression. Engineering Science and Technology: An International Journal, 2(2), 326-329.

Armstrong, J. S., \& Overton, T. S. (1977). Estimating non-response bias in mail Surveys. Journal of Marketing Research, 14(3), 396-402.

Bentler, P. M. (1990). Comparative fit indices in structural models. Psychological Bulletin, 107, 238-246.

Bollen, K. A., \& Long, J. S. (1993). Testing Structural Equation Models. Thousand Oaks, CA: Sage Publications.

Byrne, B. M. (1998). Structural equation modeling with LISREL, Prelis and Simplis: basic concepts, applications and programming. Mahwah NJ: L. Erlbaum Associates.

Chang, M., \& Harrington, J. E., Jr. (2013). Individual learning and social learning: endogenous division of cognitive labor in a population of co-evolving problem-solvers. Administrative Sciences, 3, 53-75.

Choi, Y. (2020). A study of role of perceived organizational support among sexual harassment and employees' attitudes. Journal of Asian Finance, Economics, and Business, 7(2), 229-236. https://doi.org/10.13106/jafeb.2020.vol7.no2.229

Churchill, G. A., Jr. (1979). A paradigm for developing better measures of marketing Constructs. Journal of Marketing Research, 16(February), 64-73.
Dayaram, K., \& Fung, L. (2014). Organizational learning in the Philippines: how do team and individual learning contribute? Asia Pacific Journal of Human Resources, 52, 420-442.

Dong, L. N. T., \& Phuong, N. N. D. (2018). Organizational justice, job satisfaction and organizational citizenship in higher education institutions: a research proposition in Vietnam. Journal of Asian Finance, Economics, and Business, 5(3), 113-119. http://doi.org/10.13106/jafeb.2018. vol5.no3.113

Elias, R. Z. (2006). The impact of professional commitment and anticipatory socialization on accounting students' ethical orientation. Journal of Business Ethics, 68, 83-90.

Elias, R. Z. (2007). The relationship between auditing students' anticipatory socialization and their professional commitment. Academy of Educational Leadership Journal, 11(1), 81-90.

Elias, R. Z. (2008). Auditing students' professional commitment and anticipatory socialization and their relationship to whistleblowing. Managerial Auditing Journal, 23(3), 283-294.

Fogarty, T. J. (2000). Socialization and organizational outcomes in large public accounting firms. Journal of Managerial Issues, XII(1), 13-33.

Greenfield, A. C., Jr., Norman, C. S., \& Wier, B. (2008). The effect of ethical orientation and professional commitment on earnings management behavior. Journal of Business Ethics, $83,419-434$.

Hair, J. F., Black, W. C., Babin, B. J., \& Anderson, R. E. (2010). Multivariate data analysis: a global perspective $\left(7^{\text {th }} \mathrm{ed}\right.$.). Upper Saddle River, NJ: Person Prentice Hall.

Hall, M., Smith, D., \& Langfield-Smith, K. (2005). Accountants' commitment to their profession: multiple dimensions of professional commitment and opportunities for future research. Behavioral Research in Accounting, 17, 89-109.

Herda, D. N., \& Lavelle, J. J. (2012). The auditor-audit firm relationship and its effect on burnout and turnover intention. Accounting Horizons, 26(4), 707-723.

Herda, D. N., \& Martin, K. A. (2016). The effects of auditor experience and professional commitment on acceptance of underreporting time: a moderated mediation analysis. Current Issues in Auditing, 10(2), A14-A27.

Johnson, H., \& Thomas, A. (2007). Individual learning and building organizational capacity for development. Public Administration and Development, 27, 39-48.

Kennedy, F. A., \& Widener, S. K. (2019). Socialization mechanisms and goal congruence. Accounting, Organizations and Society, $76,32-49$.

Kianto, A., Saenz, J., \& Aramburu, N. (2017). Knowledge-based human resource management practices, intellectual capital and innovation. Journal of Business Research, 81, 11-20.

Kline, R. B. (1998). Principles and practices of structural equation modeling. New York, NY: The Guilford Press.

Lui, S. S., Ngo, H., \& Tsang, A. W. (2003). Socialized to be a professional: a study of the professionalism of accountants 
in Hong Kong. International Journal of Human Resource Management, 14(7), 1192-1205.

Magni, M., Paolino, C., Cappetta, R., \& Proserpio, L. (2013). Diving too deep: how cognitive absorption and group learning behavior affect individual learning. Academy of Management Learning and Education, 12(1), 51-69.

McClaren, N., Adam, S., \& Vocino, A. (2010). Investigating socialization, work-related norms and the ethical perceptions of marketing practitioners. Journal of Business Ethics, 96(1), 95-115.

McManus, L., \& Subramaniam, N. (2014). Organizational and professional commitment of early career accountants: do mentoring and organizational ethical climate matter?. Accounting and Finance, 54, 1231-1261.

Montani, F., Courcy, F., \& Vandenberghe, C. (2017). Innovating under stress: the role of commitment and leader-member exchange. Journal of Business Research, 77, 1-13.

Mu, J., Thomas, E., Peng, G., \& Benedetto, A. D. (2017). Strategic orientation and new product development performance: the role of networking capability and networking ability. Industrial Marketing Management, 64, 187-201.

Nguyen, H. M., \& Ngo, T. T. (2020). Psychological capital, organizational commitment and job performance: a case in Vietnam. Journal of Asian Finance, Economics, and Business, 7(5), 269-278. https://doi.org/10.13106/jafeb.2020.vol7. no5.269

Nunnally, J. C., \& Bernstein, I. H. (1994). Psychometric theory. New York, NY: McGraw- Hill.

O'Brien, M. (2018). Professional socialization of accounting students: suggested activities to enhance students' experience at the anticipatory stage. Journal of Accounting and Finance, 18(9), 174-179.

Page, G. (2005). Professional socialization of valuers: what the literature and professional bodies offers. International Education Journal, 5(5), 105-116.

Peng, J., Chen, Y., Xia, Y., \& Ran, Y. (2017). Workplace loneliness, leader-member exchange and creativity: the cross-level moderating role of leader compassion. Personality and Individual Differences, 104, 510-515.

Rao Kowtha, N. (2018). Organizational socialization of newcomers: the role of professional socialization. International Journal of Training and Development, 22(2), 87-106.

Siegel, P. H., Agrawal, S., \& Rigsby, J. T. (1997). Organizational and professional socialization: institutional isomorphism in an accounting context. The Mid-Atlantic Journal of Business, 33(1), 49-68.

Smith, D., \& Hall, M. (2008). An empirical examination of a three-component model of professional commitment among public accountants. Behavioral Research in Accounting, 20(1), 75-92.

Stelmaszczyk, M. (2016). Relationship between individual and organizational learning: mediating role of team learning. Journal of Economics and Management, 26(4), 107-127.

Wier, B., Stone, D. N., \& Hunton, J. E. (2005). Does graduate business education contribute to professional accounting success?. Accounting Horizons, 19(2), 85-100.

Williams, E. A., \& Castro, S. L. (2010). The effects of teamwork on individual learning and perceptions of team performance: a comparison of face-to-face and online project settings. Team Performance Management, 16(3-4), 124-147. 
Kornchai PHORNLAPHATRACHAKORN, Khajit NA KALASINDHU /

\section{Appendix A: Measurement of all variables}

\section{Items}

Audit socialization (AS)

1. Auditors have continuously participated social activities relating to accounting and auditing aspects.

2. Auditors believe that joining auditing profession training can help effectively learn and develop their abilities, competencies and capabilities.

3. Auditors have gained knowledge from specialists and experts when they have job problems and obstacles linking to audit works.

4. Auditors are always concerned with codes of ethics, ethics and good behaviors of auditing professions.

5. Auditors have dynamically investigated, monitored, controlled, and assessed audit practices, duties, functions, activities, and responsibilities by themselves.

6. Auditors are aware of stakeholders' needs, expectations and interests in auditing professional life.

7. Auditors have focused on value, worthiness, dignity, self-confidence, merit, and pride of auditing processions.

\section{Professional commitment (PC)}

1. Auditors always adhere to auditing profession that is important for their professional lives.

2. Auditors have been very happy to work for audit jobs more than other professionals.

3. Auditors are so proud to tell other persons which they are tax auditors.

4. Auditors explicitly accept that being tax auditors reflect to professional goal achievement.

5. Auditors definitely have a sense of pride when other tax auditors accept their abilities, competencies and capabilities.

6. Auditors have professionally worked and practiced their outstanding audit jobs and works.

7. Auditors have paid attention to opportunities and futures of auditing professions.

\section{Individual learning (IL)}

1. Auditors have continuously and systematically searched for knowledge and information from various sources.

2. Auditors have joined training in new issues and topics relating to accounting, auditing and other related aspects.

3. Auditors have always participated trainings linking to problems, problems, issues, and conflicts of accounting, auditing and professional standards and regulations.

4. Auditors analyze, apply and utilize past experiences to current audit practices.

5. Auditors emphasize learning, understanding, improving, and developing ways, guidelines, methods and approaches of best audit practices

\section{Professional success (PS)}

1. Auditors can achieve the goal and objective achievement of audit practices.

2. Auditors have been accepted from other professionals relating to always their practiced audit jobs and works professionally.

3. Auditors have much confidence that they can stay in auditing professions in the current and future perspectives.

4. Auditors have maintained their existing customers and have had new customers always.

5. Auditors can present more outstanding new auditing services than expectations of stakeholders.

6. Auditors believe that they can survive and sustain in auditing professions in both current and long-term future aspects. 